\title{
OPTIMALISASI PORTOFOLIO KREDIT UNTUK PERENCANAAN EKSPANSI KREDIT PADA PERBANKAN NASIONAL
}

\author{
CREDIT PORTFOLIO OPTIMIZATION FOR CREDIT EXPANSION PLANNING ON NATIONAL BANKING
}

\author{
Rini Siswati Asnel ${ }^{* 1}$, Lukytawati Anggraeni**), dan Amzul Rifin**) \\ *) PT Bank Negara Indonesia (Persero) Tbk \\ Jl. Jendral Sudirman Kav. 1, Jakarta Pusat, Indonesia \\ ${ }^{* *}$ Departement Ilmu Ekonomi, Fakultas Ekonomi dan Manajemen, IPB University \\ Jl. Agatis Kampus IPB Darmaga, Bogor 16680, Indonesia \\ ${ }^{* * *}$ Departement Agribisnis, Fakultas Ekonomi dan Manajemen, IPB University \\ Jl. Agatis Kampus IPB Darmaga, Bogor 16680, Indonesia
}

\begin{abstract}
The aim of this study is to determine the portfolio performance in each economic sector based on return and risk of portfolio credit at 3 Sentra Kredit Menengah (SKM) under BNI WJS supervision and to find out the optimal combination or composition of the loan portfolio that provides the greatest return and the lowest risk. In this study using the Markowitz model to produce an optimal portfolio combination. The results showed recommendations of portfolio for the Jakarta Senayan Jakarta Regional especially for SKM, it was suggested to management to expansion in sectors or business with their competencies. To plan the optimal composition of the loan portfolio for credit expansion plan, the alternative of optimum portfolio from the results of this study can be used as a reference.
\end{abstract}

Keywords: loan portfolio, markowitz model, Sentra Kredit Menengah (SKM) , return, risk credit

\begin{abstract}
Abstrak: Tujuan penelitian ini adalah untuk mengetahui kinerja portofolio pada masing-masing sektor ekonomi berdasarkan return dan risiko kredit portofolio pada 3 Sentra Kredit Menengah (SKM) yang ada dibawah unit BNI WJS serta mengetahui kombinasi atau komposisi portofolio kredit optimal yang memberikan return terbesar dengan tingkat risiko yang rendah. Pada penelitian ini menggunakan model Markowitz untuk menghasilkan kombinasi portofolio yang optimal. Hasil penelitian menunjukan rekomendasi portofolio yang diambil untuk BNI Kantor Wilayah Jakarta Senayan, kepada manajemen disarankan untuk tetap melaksanakan ekspansi kredit pada sektor atau bisnis yang sesuai dengan kompetensinya. Dalam merencanakan komposisi portofolio kredit yang optimal sehubungan dengan rencana ekspansi kredit, alternatif portofolio yang optimum dari hasil penelitian ini dapat dijadikan sebagai salah satu acuan.
\end{abstract}

Kata kunci: portofolio kredit, model markowitz, Sentra Kredit Menengah (SKM), return, risiko kredit

\footnotetext{
${ }^{1}$ Corresponding author:

Email: riniasnel@gmail.com
} 


\section{PENDAHULUAN}

Bank memiliki peranan penting dalam menggerakkan sektor perekonomian dengan cara memberikan kredit agar sektor riil berkembang. Dalam penyaluran kredit kepada masyarakat/nasabah/debitur tentunya akan terdapat permasalahan yang akan dihadapi oleh pihak bank. Permasalah yang menyangkut kredit bermasalah, salah satunya seperti dana yang dipinjamkan tidak bisa dikembalikan oleh debitur dikarenakan tidak mampu memenuhi kontrak peminjaman yang disepakati. Dalam hal pemasalahan kredit ini dinamakan non performing loan atau NPL atau kredit bermasalah. Pihak bank tentu tidak ingin permasalahan ini terjadi karena akan mengurangi aset yang dimiliki oleh bank.

Lampiran Surat Edaran BI No. 13/23/DPNP tahun 2011 perihal Penetapan Manajemen Risiko Bagi Bank Umum, menjelaskan bahwa risiko kredit dapat bersumber dari berbagai aktivitas bisnis bank. Risiko kredit yang utama adalah sehubungan dengan portofolio kredit yang terkonsentrasi. Risiko konsentrasi portofolio kredit disebabkan karena terkonsentrasinya aktivitas utama perbankan, yaitu penyediaan dana kredit. Pengelompokan portofolio kredit dapat dibedakan menurut kelompok debitur, wilayah geografis, jenis produk, jenis pembiayaan, lapangan usaha dan sektor ekonomi.

Risiko konsentrasi muncul karena alokasi atau penyaluran kredit yang berlebihan (over allocation) pada satu kelompok tertentu (individual debitur/group, wilayah, sektor ekonomi, segmen bisnis atau produk tertentu dan lain sebagainya). Alokasi yang terlalu besar ini akan memberikan return memuaskan selama kondisi menguntungkan, namun saat kondisi ekonomi berubah menjadi unfavorable, kondisi over allocation berubah menjadi kerugian yang seringkali tidak mampu ditutupi oleh kemampuan permodalan bank. Fernández de Lis et al. (2000) menyimpulkan bahwa terdapat beberapa faktor yang dapat mempengaruhi level permasalahan kredit. Pertama, komposisi portofolio kredit memainkan peranan penting sebagai indikator profil risiko yang dihadapi oleh bank. Kedua, adanya ketidakefisienan bank dalam penyeleksian dan pengawasan (screening dan monitoring) debitur sehingga kualitas portofolio kredit menjadi rendah. Ketiga, lingkungan kompetisi dalam industri perbankan dapat mempengaruhi level risiko kredit yang diambil oleh bank
Penelitian tentang pembentukan portofolio optimum pada sektor ekonomi di Indonesia telah banyak dilakukan dengan menggunakan berbagai pendekatan. Wirananto (2012) merumuskan portofolio optimum menggunakan pendekatan Markowitz dengan meminimalkan variance dari masing-masing alternatif portofolio dan memasukkan variable lingkungan internal dan eksternal perusahaan. Utomo (2013) menggunakan matriks General Electric (GE) untuk pembentukan portofolio sektor ekonomi. Selain itu Silalahi (2004) yang meneliti Analisis Portofolio Kredit Untuk mengoptimalkan rencana ekspansi kredit korporasi pada PT Bank Mandiri (Persero) Tbk. Dalam penelitian ini, menganalisis kinerja kredit masingmasing sektor ekonomi dengan melihat risiko kredit dan return portofolio masing-masing sektor ekonomi, menganalisis tingkat return dan risiko sehingga membentuk suatu portofolio kredit yang optimal atau efisien dan memberikan alternatif komposisi portofolio yang optimal bagi manajemen dalam membuat perencanaan ekspansi kredit korporasi dalam rangka meningkatkan return dengan tingkat risiko minimal. Dalam penelitian ini menggunakan metode Markowitz untuk mendapatkan portofolio kredit yang optimal. Widyasari (2007) yang meneliti mengkaji tentang penyusunan portofolio kredit yang optimum untuk segmen kredit riteil, ritel tapsun, kupedes komersial dan kupedes tapsun di Bank Rakyat Indonesia Kantor cabang Majenang dengan menggunakan pendekatan Markowitz dapat diketahui tinfkat penerimaan bunga tertinggi dengan risiko rendah dihasilkan oleh segmen kredit kupedes komersial, kupedes tapsun, ritel tapsun, dan ritel komersial. Komposisi portofolio kredit optimal dengan tujuan meminimalkan risiko kredit pada Kanca BRI Majenang dapat dicapai dengan mengalokasikan kredit kepada ritel komersial $28,42 \%$, ritel tapsun $24,61 \%$, kupedes komersial $31,59 \%$ dan kupedes tapsun sebesar $15,38 \%$.

Andikno (2010) yang meneliti analisis kinerja dan strategi pengembangan portofolio kredit dengan pendekataan reward to variability ratio pada PT Bank XYZ Tbk dalam penelitian ini menganalisis kinerja yang ada saat ini pada masing-masing sektor ekonomi, mengukur tingkat penerimaan dan risiko kredit masingmasing sektor ekonomi, melakukan pengukuran kinerja portofolio kredit pada masing-masing sektor ekonomi dengan mengukur tingkat penerimaan dan risiko kredit serta menerapkan strategi pengembangan portofolio kredit dengan mempertimbangkan tingkat reward to variability ratio dan proporsi optimal 
masing-masing sektor ekonomi yang dikembangkan menggunakan metode Sharpe's dalam evaluasi kinerja portofolio kredit dengan pertimbangan metode ini sudah memperhitungkan tingkat return rata-rata portofolio yang diharapkan serta standar deviasi tingkat return disamping itu model ini juga mempertimbangkan investasi bebas risiko berupa penempatan pada Sertifikat Bank Indonesia (SBI).

Sulistyorini (2015) yang meneliti Analisis Portofolio Sektor Ekonomi Pada Segmen Menengah dan Segmen Kecil di PT Bank XYZ dalam penelitian ini diteliti bagaimana evaluasi kinerja portofolio sektor ekonomi di PT Bank XYZ untuk segmen menengah dan kecil serta mengetahui komposisi portofolio optimal menurut Single Index Model pada segmen menengah dan kecil di PT Bank XYZ. Kartika (2007) yang meneliti optimalisasi portofolio kredit segmen komersial dengan efficient frontier pada PT Bank X (Persero) Tbk pada penelitian menggunakan pendekatan Markowitz dan menggunakan spreadsheet dan tool solver untuk menentukan portofolio kredit yang optimal. Maharga (2016) yang meniliti optimaslisasi portofolio kredit komersial menggunakan model Markowitz pada PT Bank XYZ dengan tujuan menghasilkan return yang optimal dengan risiko kredit yang minimum pada 10 sektor ekonomi. Zuhdin et al. (2013) yang meneliti tentang analisis portofolio kredit perbankan umum dan syariah berdasarkan sektor ekonomi menggunakan pendekatan Modern Theory Portfolio yang dikembangkan oleh Markowitz untuk pembentukan portofolio optimal.

Selain di Indonesia, penelitian tentang pembentukan portofolio kredit yang optimum juga telah banyak dilakukan oleh perbankan di dunia seperti penelitian oleh Kazan dan Uludag (2014) berjudul Credit Portfolio Selection According To Sector In Risky Environment: Markowitz Practice. Dalam penelitian ini, diteliti bagaimana komposisi portofolio kredit yang memberikan retun yang besar dengan tingkat risiko yang kecil. Metode yang digunakan menggunakan Teori Portofolio Markowitz untuk mendapatkan kombinasi sektor pembiayaan yang mampu menghasilkan return besar dengan tingkat risiko kecil. Selama ini hanya dilakukan perhitungan risiko kredit namun belum pernah melakukan perhitungan yang efektif yang mampu menurunkan tingkat risiko dari pemberian kredit. Penelitian ini dilakukan pada bank yang ada di Turki dengan mengambil data penyaluran pinjaman selama 35 bulan kepada beberapa sektor pembiayaan. Dari hasil penelitian didapatkan bahwa komposisi portofolio kredit yang mampu memberikan return terbaik dengan tingkat risiko kecil adalah $22 \%$ untuk sektor perdagang besar dan kecil, $2 \%$ sektor tekstil dan $76 \%$ sektor kontruksi. Kesamaan dari penelitian ini menggunakan Metode Portofolio Markowitz untuk mendapatkan komposisi optimal yang mampu memberikan return terbaik dengan tingkat risiko yang kecil.

Misra (2011) yang meneliti tentang Optimization of return constraint: an application on Indian Banks. Penelitian ini bertujuan mengetahui komposisi optimal pada portofolio kredit pada salah satu bank di India. Optimalisasi portofolio ini untuk mencari komposisi pemberian kredit yang memberikan Return yang besar dengan tingkat risiko yang rendah. Penelitian ini menggunakan pendekatan Algoritma Genetika untuk mendapatkan portofolio yang optimum. Bebczuk dan Galindo (2005) dalam penenlitiannya yang berjudul financial crisis and sectoral diversivication of Argentine Banks, 1994-2004 mengkaji diversifikasi portofolio pinjaman pada bank-bank di Argentina menggunakan pendekatan Herfindhal Index. Namun, pada penelitian ini tidak mengkaji komposisi terbaik untuk mendapatkan return yang besar dengan tingkat risiko kecil pada pemberian kredit. Berger et al. (2010) dan teori diversifikasi portofolio Markowitz (1952) yang menyimpulkan bahwa diversifikasi kredit berpengaruh terhadap kinerja bank menjadi lebih baik. Tabak et al. (2011) berpendapat bahwa ada dua strategi pembentukan portofolio kredit yaitu strategi diversifikasi dan strategi konsentrasi.

Pada penelitian ini akan dilakukan pembentukan portofolio optimum sektor ekonomi. Pemilihan metode dengan pendekatan Markowitz ini merupakan suatu titik awal dalam kajian pemilihan portofolio yang mempergunakan analisis alamiah dan modern untuk dapat diterapkan dan memberikan rekomendasi atas rencana ekspansi kredit khususnya untuk manajemen BNI khususnya kantor wilayah Jakarta Senayan.

Sebagai salah satu bank terbesar di Indonesia, PT Bank Negara Indonesia (Persero), Tbk atau Bank BNI menawarkan layanan penyimpanan dana maupun fasilitas pinjaman baik pada segmen kredit korporasi, menengah dan kecil. BNI memiliki sentra-sentra kredit yang tersebar di seluruh Indonesia baik untuk sentra kredit kecil maupun sentra kredit menengah sedangkan untuk pinjaman segmen korporasi terpusat pada kantor pusat BNI. Bank BNI berkomitmen menjadi fasilitator pembangunan untuk mendukung pertumbuhan industri 
di Indonesia yang fokus pada delapan sektor industri unggulan yang prospektif diantaranya: minyak, gas dan pertambangan, telekomunikasi, kimia, agribisnis, makanan dan minuman, perdagangan besar dan eceran, kelistrikan, dan konstruksi. Pemberian kredit produktif bank BNI, di tahun 2017 berhasil membukukan pertumbuhan yang positif. Total pinjaman yang disalurkan mencapai sebesar Rp345 triliun, meningkat sebesar $12,42 \%$ dibandingkan penyaluran kredit tahun 2016 yang mencapai Rp307 triliun (Tabel 1).

Pencapaian ini menyumbang sebesar $16,3 \%$ dari total kredit BNI (Tabel 1). Pertumbuhan kredit di segmen kecil menduduki peringkat kedua setelah penyaluran kredit di segmen menengah yang tumbuh sebesar $11,4 \%$ di tahun 2017. Sedangkan segmen menengah BNI pada tahun 2017, pinjaman mencapai Rp70,3 triliun atau tumbuh 14,6\% dibandingkan tahun 2016 yang sebesar Rp50,7 triliun. Sesuai PBI No. 14/22/ PBI/2012 Bank Indonesia mewajibkan bank nasional untuk menyalurkan kredit ke usaha Menengah Kecil dan Mikro (UMKM) minimal 20\% secara bertahap mulai 2013 sampai 2018. Pada Tabel 1 terlihat bahwa komposisi portofolio BNI didominasi oleh segmen korporasi sedangkan segmen kecil kurang dari 20\%.

Dari laporan keuangan BNI tahun 2017, mayoritas kredit segmen kecil disalurkan ke sektor perdagangan restoran dan hotel yakni sebesar $61,5 \%$, sedangkan kredit segmen menengah BNI mayoritas disalurkan ke sektor perindustrian sebesar 31,5\% diikuti oleh sektor perdagangan, restoran, dan hotel sebesar 30,4\% (Tabel 2). Terlihat dari komposisi tersebut penyebaran kredit pada masing-masing sektor ekonominya belum merata. Dimana sektor bisnis tertentu mengalami pertumbuhan sangat pesat sementara bisnis lainnya mengalami pertumbuhan yang lambat. Akibatnya kredit menjadi terkonsentrasi sehingga risiko tidak tersebar secara merata.

Saat ini wilayah kerja di BNI yang memiliki portofolio terbesar salah satunya adalah Wilayah Jakarta Senayan
(WJS). Adapun kantor wilayah Jakarta Senayan ini membawahi kantor cabang dan sentra-sentra kredit baik Sentra Kredit Kecil (SKC) dan Sentra Kredit Menengah (SKM). Adapun sentra kredit yang dibawahi oleh BNI WJS terdapat 5 sentra, yaitu 2 SKC (Sentra Kredit Kecil Melawai (SKC MRC) dan Sentra Kredit Kecil Tanah Abang (SKC TAC)) dan 3 SKM (Sentra Kredit Menengah Jakarta Sudirman (SKM JDM), Sentra Kredit Menengah Jakarta Melawai (SKM JRM) dan Sentra Kredit Menengah Pondok Indah (SKM JPM)). SKC menyalurkan pinjaman untuk segmen ritel atau kecil kepada perusahaan atau indvidu dalam bentuk KUR (Kredit Usaha Rakyat) untuk pelaku UMKM, dan kredit produktif lainnya dengan besaran sampai dengan Rp15 Miliar sedangkan SKM menyalurkan kredit produktif kepada perusahaan, individu dengan besaran Rp15-300 Miliar. Pada penelitian ini fokus kepada pemberian kredit pada segmen menengah atau SKM dikarenakan pertumbuhan kredit di BNI cukup tinggi pada segmen menengah.

Evaluasi yang dilakukan terhadap kinerja portofolio sektor ekonomi kemudian dijadikan dasar untuk melakukan pembentukan portofolio optimal sektor ekonomi di perbankan. Pada tahap pembentukan portofolio, instrument investasi didefinisikan dan dipilih serta ditentukan berapa porsi dana yang akan ditanamkan dalam investasi tersebut (Bierman, 1998). Oleh sebab itu, penelitian ini diharapkan mampu memberikan rekomendasi portofolio sektor ekonomi yang dapat memberikan return yang lebih baik dibandingkan actual return.

Model Markowitz merupakan salah satu model yang dapat digunakan untuk menentukan portofolio efisien (Hastowo, 2003). Penelitian yang dilakukan Kazan dan Uludag (2014) menggunakan pendekatan model markowitz untuk mendapatkan kombinasi sektor pembiayaan yang mampu memberikan return besar dengan tingkat risiko kecil.

Tabel 1. Komposisi pemberian kredit pada Bank BNI Periode 2016-2017

\begin{tabular}{lccccc}
\hline \multirow{2}{*}{ Segmen } & 2017 & \multicolumn{4}{c}{2016} \\
\cline { 2 - 5 } & Rp Miliar & Komposisi (\%) & Rp Miliar & Komposisi (\%) & \\
\hline Korporasi & 188.026 & 54,42 & 174.073 & 56,64 & 8,02 \\
Menengah & 70.261 & 20,34 & 61.330 & 19,96 & 14,56 \\
Kecil & 56.477 & 16,35 & 50.684 & 16,49 & 11,43 \\
Luar Negeri & 30.734 & 8,90 & 21.237 & 6,91 & 44,72 \\
\hline Total & 345.496 & 100 & 307.324 & 100 & 12,42 \\
\hline Sumber: Laporan tahunan Bank BNI (2017) & & & & \\
\hline
\end{tabular}


Tabel 2. Penyaluran kredit segmen kecil dan menengah berdasarkan sektor

\begin{tabular}{lcccccc}
\hline \multirow{2}{*}{ Sektor Ekonomi } & \multicolumn{2}{c}{2017} & \multicolumn{2}{c}{2016} & \multicolumn{2}{c}{2015} \\
\cline { 2 - 6 } & Kecil & Menengah & Kecil & Menengah & Kecil & Menengah \\
\cline { 2 - 6 } & Komposisi & Komposisi & Komposisi & Komposisi & Komposisi & Komposisi \\
\hline Perindustrian & $9,5 \%$ & $3,15 \%$ & $9 \%$ & $30,4 \%$ & $9,4 \%$ & $27,5 \%$ \\
Perdagangan, restoran, dan hotel & $61,5 \%$ & $30,4 \%$ & $62,5 \%$ & $62,5 \%$ & $58 \%$ & $29,4 \%$ \\
Pertanian & $7,5 \%$ & $2,7 \%$ & $5,7 \%$ & $5,7 \%$ & $5,9 \%$ & $4,3 \%$ \\
Jasa dunia usaha & $9,5 \%$ & $3,6 \%$ & $10,4 \%$ & $10,4 \%$ & $12,1 \%$ & $10 \%$ \\
Pengangkutan, pengudangan dan komunikasi & $2,8 \%$ & $9,9 \%$ & $2,9 \%$ & $2,9 \%$ & $3,2 \%$ & $8,9 \%$ \\
Kontruksi & $4,2 \%$ & $9 \%$ & $4,5 \%$ & $4,5 \%$ & $5,4 \%$ & $10,9 \%$ \\
Listrik, gas, dan air & $0,1 \%$ & $1,1 \%$ & $0,1 \%$ & $0,1 \%$ & $0,1 \%$ & $1,5 \%$ \\
Pertambangan & $0,1 \%$ & $7,8 \%$ & $0,4 \%$ & $0,4 \%$ & $0,6 \%$ & $3,3 \%$ \\
Jasa sosial masyarakat & $4,5 \%$ & $3,8 \%$ & $1,9 \%$ & $1,9 \%$ & $5,5 \%$ & $4,2 \%$ \\
Total & $100 \%$ & $100 \%$ & $100 \%$ & $100 \%$ & $100 \%$ & $100 \%$ \\
\hline Sutayyyyyy
\end{tabular}

Sumber: Laporan tahunan Bank BNI (2017)

Tujuan penelitian ini adalah untuk mengetahui kinerja kredit masing-masing sektor ekonomi dengan melihat return dan risiko kredit portofolio masing-masing sektor ekonomi pada penyaluran kredit di Sentra Kredit Menengah serta mengetahui kombinasi atau komposisi portofolio kredit yang optimal pada Sentra Kredit Menengah di BNI Wilayah Jakarta Senayan yang memberikan return terbesar dengan tingkat risiko yang rendah.

\section{METODE PENELITIAN}

Data yang digunakan dalam penelitian ini merupakan data sekunder. Data kualitatif diperoleh dari wawancara dengan narasumber atau pejabat pemutus kredit serta pengelola kredit maupun dari rencana bisnis BNI secara keseluruhan dan rencana bisnis wilayah, khususnya BNI wilayah Jakarta Senayan (WJS).

Variabel yang digunakan dalam penelitian ini berdasarkan pada penilaian profil penyaluran kredit pada segmen menengah maupun kecil selama 5 tahun, yaitu sejak tahun 2013 sampai dengan tahun 2017 kepada sektor-sektor pembiayaan di 3 Sentra Kredit Menengah (SKM) yang ada dibawah unit BNI WJS kepada sektorsektor pembiayaan di BNI Wilayah Jakarta Senayan. Sedangkan untuk pendalaman materi penelitian dilakukan wawancara dengan para pemutus kredit dan pengelola kredit yang ada pada BNI wilayah Jakarta Senayan. Analisis data untuk pengukuran portofolio optimum dari pemberian kredit yang disalurkan oleh BNI menggunakan model Markowitz. Portofolio optimal model markowitz dirumuskan sebagai beikut:
Model Markowitz menggunakan asumsi-asumsi untuk mendapatkan nilai portofolio optimal. Asumsi-asumsi untuk mendapatkan nilai optimal. Asumsi-asumsi yang digunakan dalam model Markowitz adalah sebagai berikut: Waktu yang digunakan hanya satu periode; Tidak ada biaya transaksi; Preferensi investor hanya didasarkan pada return ekspektasi dan risiko portofolio; Tidak ada pinjaman dan simpanan bebas risiko (Jogiyanto, 2003; Sirucek dan Kren, 2015).

Untuk mendapatkan titik-titik optimum dalam suatu portofolio maka dapat ditentukan dengan metode penyelesaian optimasi dimana fungi objektif yang digunakan adalah fungsi obyektif portofolio berdasarkan model Markowitz.

Fungsi obyektif diminimalkan dengan menggunakan kendala sebagai berikut: Total proporsi yang diinvestasikan di masing-masing aktiva (sektor perkreditan) untuk seluruh sektor adalah sama dengan $100 \%$ atau 1; Proporsi dari masing-masing sektor perkreditan tidak boleh bernilai negatif; Jumlah ratarata dari seluruh return masing-masing sektor ekonomi (Ri) sama dengan return portofolio (Rp)

Michaud dalam Boangmanalu dan Komalasari (2015) menyimpulkan beberapa kelebihan teori model Markowitz antara lain: Kepuasan terhadap tujuan dan kendala yang dihadapi investor; Pembentukan portofolio dengan model Markowitz dapat mengintegrasikan secara mudah kendala-kendala yag dihadapi investor serta tujuan investor tersebut dalam struktur portofolionya; Dapat mengontrol eksposur risiko portofolio; Portofolio yang terbentuk dari Model 
Markowitz dapat digunakan untuk mengontrol eksposur portofolio terhadap beberapa komponen risiko; Suatu bentuk implementasi dari tujuan dan kondisi pasar; Portofolio yang terbentuk merupakan cerminan dari tujuan dan harapan investor, serta kondisi pasar itu sendiri; Dapat menggunakan informasi secara efisien Portofolio yang terbentuk merupakan portofolio yang menyediakan berbagai informasi, sehingga investor dapat membaca dan mengolah informasi tersebut dengan mudah. Secara matematis, rumus untuk menghitung portofolio optimal berdasarkan model Markowitz adlah sebagai berikut:

Fungsi Tujuan (Jogiyanto, 2003)

1. Minimum portofolio varian beberapa sektor ekonomi

$$
\sigma_{p}^{2}=\sum_{i=1}^{n} w_{i}^{2} \sigma_{i}^{2}+\sum_{i=1}^{n} \sum_{j=1}^{n} w_{i} w_{j} \sigma_{i j}
$$

2. Maksimum return portofolio

$$
E\left(R_{p}\right)=\sum_{i=1}^{n}\left(w_{i} \cdot E\left(R_{i}\right)\right)
$$

Dengan kendala

Wi $\geq 0$ untuk $\mathrm{i}=1$ sampai dengan $\mathrm{n}$

$$
E\left(R_{p}\right)=\sum_{i=1}^{n}\left(w_{i} \cdot E\left(R_{i}\right)\right)
$$

Keterangan: i (kovarian sektor ekonomi); Wi (porporsi sektor ekonomi i $(\mathrm{i}=1,2,3, \ldots, \mathrm{n}))$; $\mathrm{Wj}$ (proporsi sektor ekonomi j $(j=1,2,3, \ldots, n)$ ); i2 (varian sektor ekonomi ke-i ); ij (kovarian sektor ekonomi i dan j); p2 (varian portofolio); Ri (return sektor ekonomi I); Rp (return portofolio); n (jumlah sektor ekonomi). Kerangka pemikiran penelitian selengkaponya pada Gambar 1.

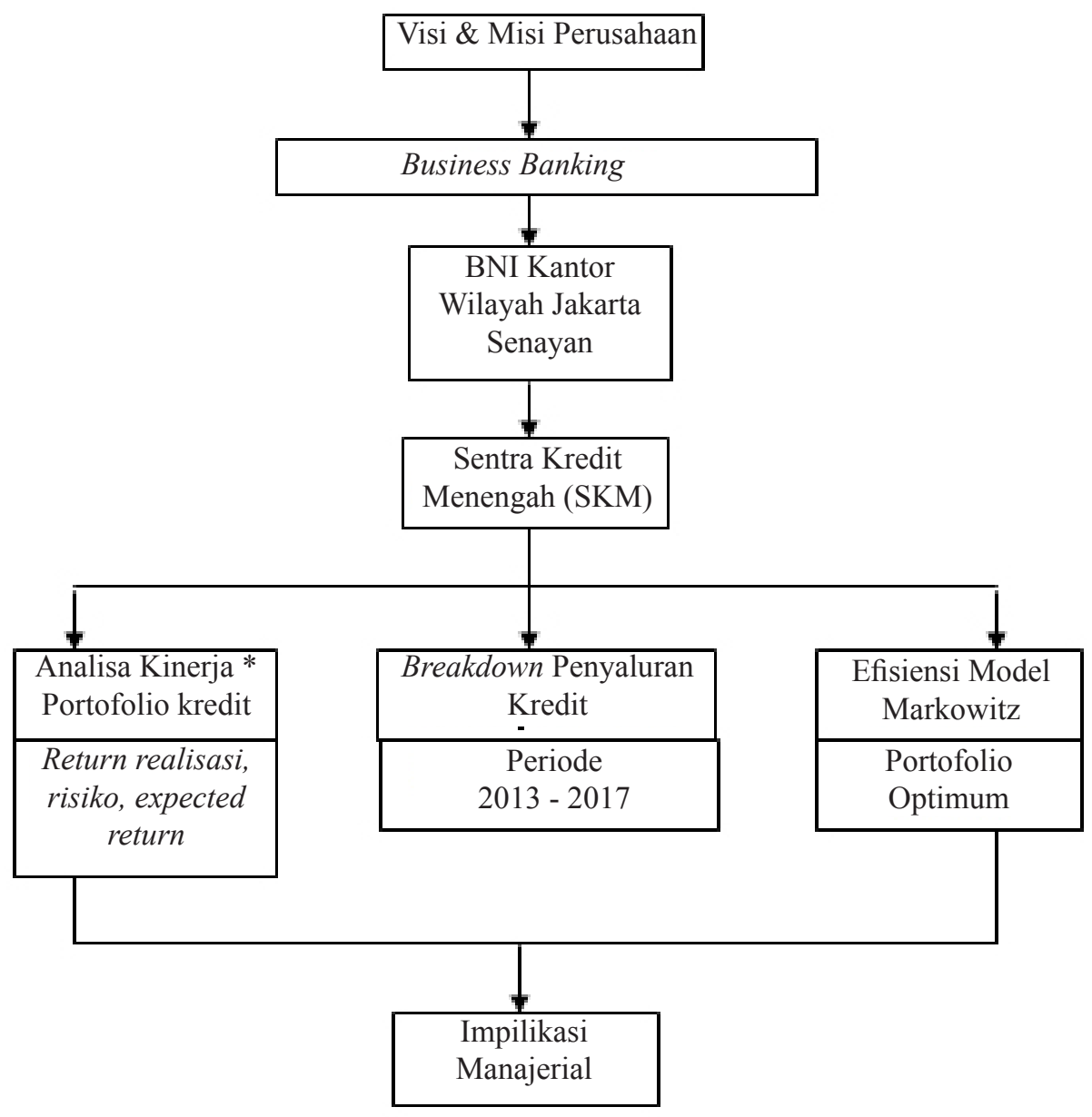

Gambar 1. Kerangka pemikiran penelitian 


\section{HASIL}

\section{Analisis Return dan Risiko Kredit}

\section{Analisis Return Realisasi Kredit}

Berdasarkan rata-rata return realisasi per bulan pada SKM JRM tertinggi pada sektor ekonomi listrik, gas dan air yang paling tinggi $(1,45 \%)$, kemudian oleh sektor Perdagangan, Restoran, \& Hotel (0,92\%), sektor Pengangkutan, Pergudangan, \& Komunikasi $(0,90 \%)$, Konstruksi $(0,89 \%)$. Dari rata-rata return realisasi tersebut menunjukan bahwa penyaluran kredit ke sektor listrik, gas, dan air lebih efektif dibandingkan dengan sektor lainnya (Tabel 3). Rendahnya realisasi penerimaan bunga yang diperoleh dari sektor Jasajasa Dunia Usaha disebabkan oleh beberapa hal yaitu jenis kredit yang diberikan pada sektor ini kebanyakan kepada debitur dibidang konstruksi non bangunan dengan pola penarikan kredit berdasarkan progress pekerjaan, nominal kontrak atau pekerjaan yang didapat oleh debitur, dan jangka waktu pekerjaan sehingga pola pembayaran bunganya berfluktuatif dan cenderung menurun sampai dengan proyek selesai.

Rata-rata return realisasi per bulan pada SKM JDM tertinggi pada sektor Jasa-jasa Sosial Masyarakat $(1,29 \%)$, kemudian oleh sektor Pertambangan $(1,04 \%)$ sektor Listrik, Gas, \& Air (0,99\%). Dari rata-rata return realisasi tersebut menunjukan bahwa penyaluran kredit di SKM JDM ke sektor Jasa-jasa Sosial Masyarakat lebih efektif dibandingkan dengan sektor lainnya. Rendah nya realisasi penerimaan bunga yang diperoleh dari sektor industri pengolahan disebabkan oleh beberapa hal yaitu jenis kredit yang banyak diberikan pada debitur dibidang industri pengolahan adalah kredit-kredit investasi yang pola pembayaran bunganya menurun seiring dengan menurunya jumlah pinajaman.

Rata-rata return realisasi per bulan ada SKM JPM tertinggi pada sektor Pertanian, Perburuan, dan Sarana Pertanian $(1,07 \%)$, kemudian oleh sektor konstruksi $(1,02 \%)$, dan sektor industri pengolahan $(0,91 \%)$. Dari rata-rata return realisasi tersebut menunjukan bahwa penyaluran kredit di SKM JPM ke sektor Pertanian, Perburuan, dan Sarana Pertanian lebih efektif dibandingkan dengan sektor lainnya. Rendahnya realisasi penerimaan bunga yang diperoleh dari sektor Pertambangan disebabkan oleh beberapa hal salah satunya dari jenis kredit yang banyak diberikan pada debitur dibidang pertambangan adalah kredit-kredit investasi yang pola pembayaran bunganya dilakukan per triwulan atau termin proyek serta sifatnya kredit aflopend dengan saldo menurun sampai dengan proyek selesai.

\section{Analisis Expected Return}

Berdasarkan Tabel 4 rata-rata expected return per bulan untuk SKM JRM pada masing-masing sektor ekonomi hanya sektor ekonomi Listrik, Gas dan Air yang memiliki return realisasi diatas expected return atau target pengembalian yang diharapkan. Pada SKM JDM hanya sektor jasa-jasa social masyarakat yang memiliki return realisasi diatas expected return atau target pengembalian yang diharapkan sedangkan pada SKM JPM hanya sektor Konstruksi yang memiliki return memiliki return realisasi sama dengan expected return atau target pengembalian yang diharapkan sedangkan sektor-sektor ekonomi lainnya belum memenuhi target pengembalian yang diharapkan.

Tabel 3, Return realisasi kredit masing-masing sektor ekonomi

\begin{tabular}{|c|c|c|c|}
\hline \multirow[t]{2}{*}{ Sektor } & \multicolumn{3}{|c|}{ Rata-Rata Return Realisasi Kredit per bulan 2013 -2017 (\%) } \\
\hline & JRM & JDM & JPM \\
\hline Industri Pengolahan & 0,88 & 0,94 & 0,91 \\
\hline Jasa-jasa Dunia Usaha & 0,85 & 0,95 & 0,85 \\
\hline Jasa-jasa Sosial Masyarakat & 0,80 & 1,29 & 0,88 \\
\hline Konstruksi & 0,89 & 0,97 & 1,02 \\
\hline Pengangkutan, Pergudangan, \& Komunikasi & 0,90 & 0,98 & 0,77 \\
\hline Perdagangan, Restoran, \& Hotel & 0,92 & 0,96 & 0,88 \\
\hline Pertanian, Perburuan, \& Sarana Pertanian & 0,86 & 0,95 & 1,07 \\
\hline Listrik, Gas, \& Air & 1,45 & 0,99 & 0,87 \\
\hline Pertambangan & 0,81 & 1,04 & 0,81 \\
\hline Rata-Rata & 0,93 & 1,01 & 0,90 \\
\hline
\end{tabular}




\section{Analisis Tingkat Risiko Kredit}

Sebagaimana hasil perhitungan tingkat risiko pad Tabel 5. Tingkat risiko pemberian kredit yang disalurkan oleh SKM JRM pada sektor-sektor ekonomi menunjukan sektor Listik, Gas dan Air memiliki tingkat risiko yang palin tinggi, yakni 2,220\% dibandingkan sektor ekonomi lainnya sedangkan sektor Kontruksi memiliki tingkat risiko terendah yakni sebesar 0,093\%. Apabila tingkat keuntungan yang dihasilkan dari masingmasing sektor diharapkan dengan tingkat risiko dari masing-masing sektor maka pemberian kredit pada sektor Listik, Gas dan Air akan memiliki risiko yang lebih besar karena mendapatkan return yang juga paling tinggi. Jadi terdapat hubungan antara besarnya return dengan risiko yang dihadapi.
Tingkat risiko pemberian kredit yang disalurkan oleh SKM JDM pada sektor-sektor ekonomi menunjukan sektor Pertambangan memiliki tingkat risiko tinggi sebesar $0,585 \%$ selain itu sektor Jasa-Jasa Sosial Masyarakat juga memiliki tingkat risiko tinggi yakni $0,543 \%$ dibandingkan sektor ekonomi lainnya sedangkan sektor Perdagangan, Restoran, dan Hotel merupakan sektor yang memiliki tingkat risiko terendah, yakni sebesar $0,073 \%$. Apabila tingkat keuntungan yang dihasilkan dari masing-masing sektor diharapkan dengan tingkat risiko dari masing-masing sektor maka pemberian kredit pada sektor Jasa-Jasa Sosial Masyarakat akan memiliki risiko yang lebih besar karena mendapatkan return yang juga paling tinggi. Jadi terdapat hubungan antara bessarnya return dengan risiko yang dihadapi.

Tabel 4, Tingkat keuntungan yang diharapkan (expected return) masing-masing sektor ekonomi

\begin{tabular}{lcccccc}
\hline \multirow{2}{*}{ Sektor } & \multicolumn{3}{c}{ Rata-rata Return per Bulan 2013 - 2017 (\%) } \\
\cline { 2 - 7 } & \multicolumn{2}{c}{ JRM } & \multicolumn{3}{c}{ JDM } & \multicolumn{3}{c}{ JPM } \\
\cline { 2 - 7 } & expected & relalisasi & expected & relalisasi & expected & relalisasi \\
\hline Industri Pengolahan & 0,97 & 0,88 & 1,01 & 0,94 & 0,98 & 0,91 \\
Jasa-jasa Dunia Usaha & 1,01 & 0,85 & 1,03 & 0,95 & 0,99 & 0,85 \\
Jasa-jasa Sosial Masyarakat & 0,89 & 0,80 & 1,05 & 1,29 & 1,04 & 0,88 \\
Konstruksi & 0,99 & 0,89 & 1,01 & 0,97 & 1,02 & 1,02 \\
Pengangkutan, Pergudangan, \& Komunikasi & 0,99 & 0,90 & 1,05 & 0,98 & 0,95 & 0,77 \\
Perdagangan, Restoran, \& Hotel & 1,02 & 0,92 & 1,02 & 0,96 & 0,94 & 0,88 \\
Pertanian, Perburuan, \& Sarana Pertanian & 0,89 & 0,86 & 0,99 & 0,95 & 1,10 & 1,07 \\
Listrik, Gas, \& Air & 0,66 & 1,45 & 1,02 & 0,99 & 0,89 & 0,87 \\
Pertambangan & 0,88 & 0,81 & 0,95 & 1,04 & 0,92 & 0,81 \\
\hline \multicolumn{1}{c}{ rata-rata } & 0,92 & 0,93 & 1,02 & 1,01 & 0,98 & 0,90 \\
\hline
\end{tabular}

Tabel 5. Tingkat risiko masing-masing sektor ekonomi

\begin{tabular}{|c|c|c|c|}
\hline \multirow[t]{2}{*}{ Sektor } & \multicolumn{3}{|c|}{ Tingkat Resiko / Standar Deviasi (\%) } \\
\hline & JRM & JDM & JPM \\
\hline Industri Pengolahan & 0,107 & 0,076 & 0,075 \\
\hline Jasa-jasa Dunia Usaha & 0,174 & 0,101 & 0,062 \\
\hline Jasa-jasa Sosial Masyarakat & 0,334 & 0,543 & 0,245 \\
\hline Konstruksi & 0,093 & 0,095 & 0,070 \\
\hline Pengangkutan, Pergudangan, \& Komunikasi & 0,119 & 0,069 & 0,105 \\
\hline Perdagangan, Restoran, \& Hotel & 0,114 & 0,073 & 0,068 \\
\hline Pertanian, Perburuan, \& Sarana Pertanian & 0,182 & 0,145 & 0,154 \\
\hline Listrik, Gas, \& Air & 2,220 & 0,126 & 0,095 \\
\hline Pertambangan & 0,263 & 0,585 & 0,079 \\
\hline Rata-rata & 0,401 & 0,201 & 0,106 \\
\hline
\end{tabular}


Tingkat risiko pemberian kredit yang disalurkan oleh SKM JPM pada sektor-sektor ekonomi menunjukan sektor Jasa-jasa Sosial Masyarakat memiliki tingkat risiko yang paling tinggi, yakni $0,245 \%$ diikuti sektor Pertanian, Perburuan, dan Sarana Pertanian sebesar $0,154 \%$ dibandingkan sektor ekonomi lainnya sedangkan sektor Jasa-Jasa Dunia Usaha yang memiliki tingkat risiko terendah, yakni sebesar $0,062 \%$. Apabila tingkat keuntungan yang dihasilkan dari masing-masing sektor diharapkan dengan tingkat risiko dari masingmasing sektor maka pemberian kredit pada sektor JasaJasa Sosial Masyarakat akan memiliki risiko yang lebih besar karena mendapatkan return yang juga paling tinggi. Jadi terdapat hubungan antara bessarnya return dengan risiko yang dihadapi.

\section{Optimalisasi Portofolio Kredit Pada SKM}

Analisis optimlisasi kredit dihitung dengan menggunakan pendekatan model Markowitz. Pada Tabel 6 dapat dilihat bahwa portofolio kredit segmen menengah atau SKM di BNI WJS kombinasi portofolio kredit pada SKM JRM dengan tingkat pengembalian portofolio atau return dan risiko yang paling optimal adalah dengan komposisi sektor Industri Pengolahan sebesar 17,89\%, sektor Jasa-jasa Dunia Usaha sebesar $11,10 \%$, sektor Jasa-jasa Sosial Masyarakat sebesar 9,50\%, sektor Konstruksi sebesar 13,32\%, sektor Pengangkutan, Pergudangan, \& Komunikasi sebesar $11,12 \%$, sektor Perdagangan, Restoran, \& Hotel sebesar 15,65\%, sektor Pertanian, Perburuan, \& Sarana Pertanian sebesar 7,25\%, sektor Listrik, Gas, \& Air sebesar $11,11 \%$, dan sektor Pertambangan sebesar $3,06 \%$ memberikan nilai expected return sebesar $1,00 \%$ dengan risiko sebesar $0,401 \%$. Artinya, bahwa untuk pembentukan portofolio kredit diwaktu yang akan datang apabila diterapkan komposisi kredit yang sama dengan kondisi rata-rata maka akan memberikan tingkat pengembalian portofolio sebesar $1,00 \%$ dengan tingkat risiko $0,401 \%$. Jika dibandingkan portofolio eksisting dengan portofolio hasil optimalisasi pada SKM JRM sektor Industri pengolahan, sektor perdagangan, restoran, dan hotel, sektor konstruksi dan jasa-jasa dunia usaha yang menjadi portofolio dominan pada SKM JRM harus dikurangi dengan memberikan share yang lebih tinggi kepada sektor jasa-jasa sosial masyarakat, sektor listrik, gas dan air, sektor pertanian, perburuan dan sarana pertanian dan sektor pertambangan.

Kombinasi portofolio kredit pada SKM JDM dengan tingkat pengembalian portofolio atau return dan risiko yang paling optimal adalah dengan komposisi komposisi Industri Pengolahan sebesar 19,16\%, sektor Jasa-jasa Dunia Usaha sebesar 10,36\%, sektor Jasa-jasa Sosial Masyarakat sebesar 7,58\%, sektor Konstruksi sebesar 13,34\%, sektor Pengangkutan, Pergudangan, \& Komunikasi sebesar $11,05 \%$, sektor Perdagangan, Restoran, \& Hotel sebesar 12,62\%, sektor Pertanian, Perburuan, \& Sarana Pertanian sebesar 5,96\%, sektor Listrik, Gas, \& Air sebesar 11,06\%, dan sektor Pertambangan sebesar $8,87 \%$ memberikan nilai expected return sebesar $1,06 \%$ dengan risiko sebesar $0,201 \%$. Artinya, bahwa untuk pembentukan portofolio kredit diwaktu yang akan datang apabila diterapkan komposisi kredit yang sama dengan kondisi rata-rata maka akan memberikan tingkat pengembalian portofolio sebesar $1,06 \%$ dengan tingkat resiko 0,201\%. Jika dibandingkan portofolio eksisting dengan portofolio hasil optimalisasi pada SKM JDM sektor Industri pengolahan, sektor perdagangan, restoran, dan hotel, sektor konstruksi, sektor jasa-jasa dunia usaha, dan sektor pengangkutan, pergudangan dan komunikasi yang menjadi portofolio dominan pada SKC JDM harus dikurangi dengan memberikan share yang lebih tinggi kepada, sektor jasa-jasa sosial masyarakat, sektor listrik, gas dan air, sektor pertanian, perburuan dan sarana pertanian dan sektor pertambangan.

Kombinasi portofolio kredit pada SKM JPM dengan tingkat pengembalian portofolio atau return dan risiko yang paling optimal adalah dengan komposisi sektor Industri Pengolahan sebesar $14.76 \%$, sektor Jasajasa Dunia Usaha sebesar 11,14\%, sektor Jasa-jasa Sosial Masyarakat sebesar 18,70\%, sektor Konstruksi sebesar 10,89\%, sektor Pengangkutan, Pergudangan, \& Komunikasi sebesar $11,14 \%$, sektor Perdagangan, Restoran, \& Hotel sebesar 18,70\%, sektor Pertanian, Perburuan, \& Sarana Pertanian sebesar 4.56\%, sektor Listrik, Gas, \& Air sebesar $11.08 \%$, dan sektor Pertambangan sebesar $8,76 \%$ ternyata memberikan nilai expected return sebesar $1,09 \%$ dengan risiko sebesar $0,106 \%$. Artinya, bahwa untuk pembentukan portofolio kredit diwaktu yang akan datang apabila diterapkan komposisi kredit yang sama dengan kondisi rata-rata maka akan memberikan tingkat pengembalian portofolio sebesar 1,09 dengan tingkat resiko $0,106 \%$. Jika dibandingkan portofolio eksisting dengan portofolio hasil optimalisasi pada SKM JPM sektor sektor perdagangan, restoran, dan hotel, sektor Industri pengolahan, sektor konstruksi dan sektor jasa-jasa dunia usaha yang menjadi portofolio dominan pada SKC JPM harus dikurangi dengan memberikan share yang lebih 
tinggi kepada sektor jasa-jasa sosial masyarakat, sektor listrik, gas dan air, sektor pertanian, perburuan dan sarana pertanian, sektor pengangkutan, pergudangan, dan komunikasi, dan sektor pertambangan.

Portofolio optimum diatas, dapat direkomendasikan pada masing-masing sentra kredit kecil atas komposisi penyaluran kredit pada masing-masing sektor ekonomi untuk mendapatkan return yang lebih baik dengan tingkat risiko kredit yang lebih rendah dibandingkan portofolio eksisting. Tabak et al. (2011) berpendapat bahwa ada dua strategi pembentukan portofolio kredit, yaitu strategi diversifikasi dan strategi konsentrasi. Bebzuk dan Galindo (2005) meneliti tentang pengaruh dan evolusi diversifikasi portofolio kredit pada saat krisis keuangan tahun 2001 - 2002 di Argentina. Hasil penelitiannya menyimpulkan bahwa diversifikasi berpengaruh positif terhadap return. Penelitian Rossie et al. (2009) menggunakan managerial behavior model untuk bank di Austria menyimpulkan bahwa diversifikasi berpengaruh negatif efisiensi biaya, meningkatkan profit dan mengurangi risiko. Berger et al. (2010) dan teori diversifikasi portofolio Markowitz (1952) yang menyimpulkan bahwa diversifikasi kredit berpengaruh terhadap kinerja bank menjadi lebih baik.

Acharya et al. (2002) dalam Tabak et al. (2011) merekomendasikan konsentrasi perbankan atas aktivitasnya di sektor yang spesifik dengan mengambil keuntungan dari kemampuan pengelolaan bisnis di sektor tersebut. Hayden et al. (2006) berpendapat bahwa diversifikasi hanya berpengaruh signifikan terhadap return pada bank di Jerman dengan tingkat risiko menengah, sedangkan Mercieca et al. (2007) dari hasil penelitiannya menyarankan bank kecil untuk meningkatkan kinerja dan berekspansi pada business line dimana bank tersebut mempunyai comparative advantages. Christiani (2011) yang meneliti tingkat diversifikasi sektor ekonomi terhadap profitabilitasnya dan probabilitas kegagalan bank yang sudah listed di bursa menyimpulkan bahwa nilai asset bank terbukti mampu memperjelas kekuatan hubungan antara diversifikasi kredit terhadap profotabilitas dan probabilitas kegagalan bank.

Fernández de Lis et al. (2000) menyimpulkan bahwa terdapat beberapa faktor yang dapat mempengaruhi level permasalahan kredit. Pertama, komposisi portofolio kredit memainkan peranan penting sebagai indikator profil risiko yang dihadapi oleh bank. Kedua, adanya ketidakefisienan bank dalam penyeleksian dan pengawasan (screening dan monitoring) debitur sehingga kualitas portofolio kredit menjadi rendah. Ketiga, lingkungan kompetisi dalam industri perbankan dapat mempengaruhi level risiko kredit yang diambil oleh bank. Berdasarkan pada faktor yang mempengaruhi level permasalahan kredit di atas, maka komposisi portofolio kredit dan kegiatan monitoring bank menjadi sangat penting. Hal ini disebabkan jika komposisi portofolio kredit tidak dikelola dengan baik bisa berakibat pada peningkatan level permasalahan kredit yang berdampak pada risiko default. Apalagi kesempatan bank untuk gagal secara endogen dipengaruhi oleh pilihan struktur portofolio kredit bank yang bersangkutan (Winton, 1999).

Tabel 6. Optimalisasi portofolio kredit pada sentra kredit menengah

\begin{tabular}{|c|c|c|c|c|c|c|}
\hline \multirow[t]{3}{*}{ Sektor } & \multicolumn{6}{|c|}{ Portofolio Kredit (\%) } \\
\hline & \multicolumn{2}{|c|}{ JRM } & \multicolumn{2}{|c|}{ JDM } & \multicolumn{2}{|c|}{ JPM } \\
\hline & Optimalisasi & Eksisting & Optimalisasi & Eksisting & Optimalisasi & Eksisting \\
\hline Industri Pengolahan & 17,89 & 23,68 & 19,16 & 23,68 & 14,76 & 20,22 \\
\hline Jasa-jasa Dunia Usaha & 11,10 & 11,16 & 10,36 & 11,16 & 10,24 & 11,54 \\
\hline Jasa-jasa Sosial Masyarakat & 9,50 & 3,96 & 7,58 & 3,96 & 9,87 & 5,89 \\
\hline Konstruksi & 13,32 & 22,09 & 13,34 & 22,09 & 10,89 & 12,78 \\
\hline Pengangkutan, Pergudangan, \& Komunikasi & 11,12 & 6,41 & 11,05 & 16,15 & 11,14 & 2,97 \\
\hline Perdagangan, Restoran, \& Hotel & 15,65 & 23,49 & 12,62 & 20,07 & 18,70 & 25,63 \\
\hline Pertanian, Perburuan, \& Sarana Pertanian & 7,25 & 3,75 & 5,96 & 2,71 & 4,56 & 0,33 \\
\hline Listrik, Gas, \& Air & 11,11 & 3,68 & 11,06 & 5,76 & 11,08 & 3,46 \\
\hline Pertambangan & 3,06 & 1,78 & 8,87 & 4,88 & 8,76 & 6,43 \\
\hline Return & 1,00 & 0,93 & 1,06 & 1,01 & 1,09 & 0,9 \\
\hline Tingkat Risiko & 0,401 & 0,401 & 0,201 & 0,201 & 0,106 & 0,106 \\
\hline
\end{tabular}


Hasil penelitian ini memperkuat penelitian yang dilakukan oleh Bebzuk dan Galindo (2005) bahwa diversifikasi dapat meningkatkan return Bank BNI khususnya BNI WJS sebagai bank yang berada pada kategori bank Umum Kelompok Usaha (BUKU) IV atau sebagai bank dengan size besar. Sejalan dengan pendapat Hayden (2006) dan Mercieca et al. (2007) serta Christina (2011) maka konsentrasi tidak cocok apabila diterapkan pada BNI.

\section{Implikasi Manajerial}

Portofolio optimum hasil penelitian, dapat direkomendasikan pada masing-masing SKM yang ada di BNI WJS atas komposisi penyaluran kredit pada masing-masing sektor ekonomi karena memberikan tingkat return yang lebih tinggi dengan tingkat risiko yang sama dibandingkan portofolio saat ini. Pada portofolio SKM JRM, JDM dan JRM yang memiliki portofolio dominan pada sektor Industri pengolahan, sektor perdagangan, restoran dan hotel serta sektor konstruksi harus dikurangi bobotnya dengan memberikan share yang lebih tinggi pada sektor jasajasa dunia usaha, sektor jasa, jasa sosial masyarakat, sektor pertanian, perburuan, dan sarana pertanian, sektor listrik, gas, dan air, sektor pengangkutan, pergudangan dan komunikasi serta sektor pertambangan.

Selain melihat hasil kombinasi portofolio kredit yang optimum yang dihasilkan dengan model Markowitz, perusahaan hendaknya tetap mempertimbangkan faktor-faktor internal yang dimiliki perusahaan yang dapat mendukung kebijaksanaan perkereditan, yaitu meningkatkan kesiapan sumber daya manusia yang dimiliki dengan memberikan pelatihan secara berkala untuk meningkatkan kemampuan karyawan dalam menguasai bidang pekerjaannya serta mampu untuk mengembangkannya, meningkatkan kemampuan sarana dan prasarana yang dimiliki saat ini berupa system informasi teknologi dan system administrasi kredit yang akurat sehingga dapat memberikan informasi yang tepat bagi manajemen dalam mengambil keputusan. Analisis faktor eksternal juga menjadi perhatian penting karena operasional bank di Indonesia harus tunduk kepada ketentuan dan peraturan yang ditetapkan oleh Otoritas Jasa Keuangan (OJK). Adanya peraturan-peraturan dibidang dibidang perkreditan yang sudah berjalan maupun yang akan datang akan sangat menentukan kebijakan bank dalam bidang perkreditan

\section{KESIMPULAN DAN SARAN}

\section{Kesimpulan}

Rata-rata return realisasi pada periode 2013-2017 pada 3 SKM, hanya SKM JRM yang telah melampaui target return yang diharapkan. Rata-rata tingkat risiko pada periode 2013-2017 tertinggi pada SKM JRM diikuti oleh SKM JDM dan SKM JPM terendah. Hasil optimalisasi portofolio kredit pada SKM JRM menghasilkan tingkat expected return sebesar 1,00\% dan tingkat risiko sebesar $0,401 \%$, pada SKM JDM menghasilkan tingkat expected return sebesar 1,06\% dan tingkat risiko sebesar 0,201\%, dan pada SKM JPM menghasilkan tingkat expected return sebesar $1,09 \%$ dan tingkat risiko $0,106 \%$. Hasil optimaslisasi portofolio pada SKM menghasilkan tingkat return yang lebih tinggi dari return portofolio saat ini dengan tingkat risiko yang sama.

\section{Saran}

Pendekatan portofolio dengan pendekatan Model Markowitz dapat digunakan untuk membentuk portofolio sektor ekonomi sehingga memudahkan bagi pembuat kebijakan menentukan sektor ekonomi mana yang akan dikelola. Penelitian selanjutnya dengan pendekatan Penelitian selanjutnya dapat menggunakan metode lainnya untuk pembentukan portofolio optimum dan melakukan penelitian lebih spesifik. Penelitian selanjutnya agar meneliti risiko lainnya yang terkait dengan risiko kredit sehingga dihasilkan penelitian yang lebih mendalam mengenai risiko kredit.

\section{DAFTAR PUSTAKA}

Acharya V, Hasan I, Saunders A. 2002. Should Bank be Diversified ? Evidence from individual bank loan portfolio. Bank for International Settlement working papar. http://www.bis.org/publ/worl118. pdf. [20 Mar 2018].

Andiko Z. 2010. Analisis kinerja dan strategi pengembangan portofolio kredit dengan metode reward to variability ratio pada PT Bank XYZ Tbk [tesis]. Bogor: Institut Pertanian Bogor.

Bebczuk R, Galindo A. 2005. Financial cricis and sectoral diversicvication of Argentine Banks 1994-2004. Applied Financial Economics 18(3): 199-211. 
Berger AN, Hasan I, Zhou M. 2010. The effects of focus versus diversification on bank performance: evidence from Chinese Banks. Journal of Banking and Finance 34(7): 1417-1435.

Bierman H. 1998. A Utility Approach to the portfolio allocation decision and the investment horizon. Journal of Portfolio Management 25(1): 81-87.

Boangmanalu AIM, Komalasari PT. 2015. Portofolio Markowitz: uji optimal holding period dan kinerja portofolio berdasarkan kriteria risiko dan target return. Jurnal Manajemen Indonesia 15(2):115-126.

Christiani A. 2011. Diversifikasi kredit terhadap profitabilitas dan probabilitas kegagalan bank. Jurnal Keuangan dan Perbankan 15(3): 428436.

Fernández de Lis S, Martínez J, Saurina J. 2000. Credit Growth, Problem Loans and Credit Risk Provisioning in Spain. Banco De Españal Documento de Trobajo N 31(12):18-30.

Hastowo S. 2003. Analisis portofolio kredit ritel untuk perencana ekspansi kredit kantor cabang BRI [Tesis]. Bogor : Institut Pertanian Bogor.

Jogiyanto HM. 2003. Teori Portofolio dan Analisis Investasi. Ed ke-3. Yogyakarta: BPFE.

Kartika TI. 2007. Optimalisasi portofolio kredit segmen komersial dengan efisiensi frontier pada PT Bank $\mathrm{X}$ (Persero) Tbk [tesis]. Bogor: Institut Pertanian Bogor.

Kazan H, Uludag K. 2014. Credit portfolio selection according to sector in risky environment: Markowitz practice. Jurnal Asian Economic and Finance 4(9): 1208-1219.

Maharga. 2016. Optimalisasi portofolio kredit komersial menggunakan model Markowitz: Studi kasus pada PT Bank XYZ [tesis]. Yogyakarta: Universitas Gajah Mada.

Mercieca S, Scheck K, Wolfe S. 2007. Small European Bank: benefits from diversification. Journal of Banking and Finance 31(7): 1975-1998.

Michaud RO. 1989. The Markowitz optimization enigma: is optimized optimal?. Financial Analysts Journal 45(1):31-42

Misra KA. 2011. Optimization of return risk constraint: an application on Indian Banks. International
Conference of Financial Management and Economics 11(68): 353-357.

Rossie S, Schwaiger M, Winkler G. 2009. How loan portfolio diversivication affects risk, efficiency an capitalization: a managerial behavior model for Austrian Banks. Journal of Banking Finance 291(1): 141-151.

Silalahi YLS. 2004. Analisis portofolio kredit untuk mengoptimalkan rencana ekspansi kredit korporasi pada PT Bank Mandiri (Persero) Tbk [tesis]. Bogor: Institut Pertanian Bogor.

Sirucek M, Kren L. 2015. Application of Markowitz portfolio theory by building optimal portfolio on the US stock market. Wall Street Journal 63(4): 1375-1386.

Sulistyorini DD. 2015. Analisis portofolio sektor ekonomi pada segmen menengah dan segmen kecil di PT Bank XYZ [tesis]. Bogor: Institut Pertanian Bogor.

Tabak BM, Fazio DM, Daniel OC. 2011. The effects of loan portfolio concentration on Brazilian Bank's return and risk. Journal of Banking and Finance 35(11): 3065-3076.

Untung B. 2000. Kredit Perbankan di Indonesia. Yogyakarta(ID): Andi.

Utomo BS. 2003. Analisis portofolio kredit studi kasus di PT Bank Mandiri [tesis]. Bogor: Institut Pertanian Bogor.

Widyasari, H. 2007. Optimalisasi portofolio kredit Bank Rakyat Indonesia Kantor Cabang Majenang [tesis]. Yogyakarta: Univessitas Gadjah Mada.

Winton A. 1999. Don't Put All Your Eggs in One Basket? Diversification and Specialization in Lending. Working Paper No.00-16. University of Minnesota. http://www.ssrn.com/abstract. [20 Mar 2018].

Wirananto H. 2002. Optimalisasi portofolio kredit studi kasus pada PT Bank Rakyat Indonesia (Persero) Kantor Cabang Tanjungkarang [tesis]. Bogor: Institut Pertanian Bogor.

Zuhdin AR, Adawiyah WR, Najmudin. 2013. Analisis portofolio kredit perbankan umum dan syariah berdasarkan sektor ekonomi. Jurnal Ekonomi Bisnis 12(1): 1-10. 